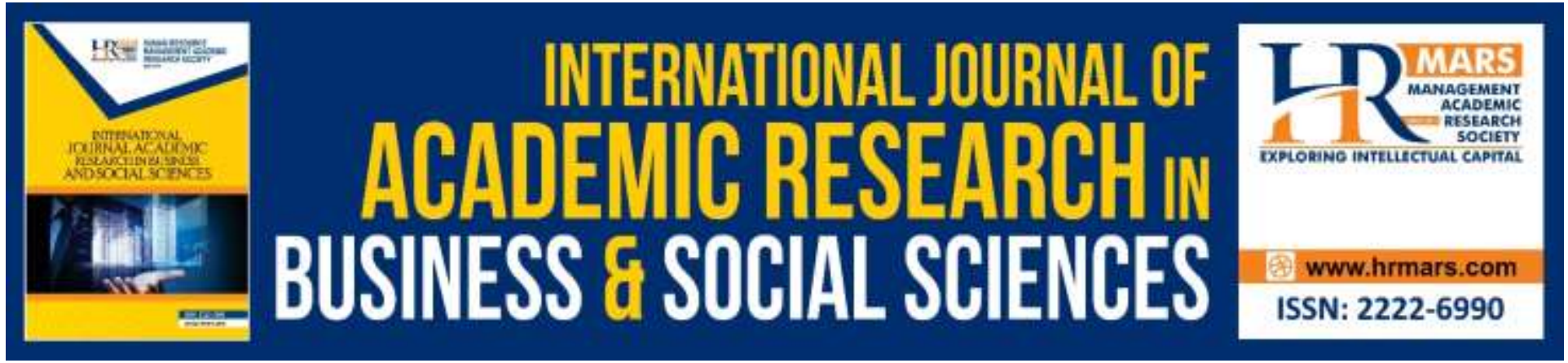

\title{
Herdsmen-Farmers Crisis and its Implication on Human Resource Management: The Nigeria Experience
}

\author{
Alonge Opeyemi Mojisola
}

To Link this Article: http://dx.doi.org/10.6007/IJARBSS/v9-i10/6458

DOI: $10.6007 /$ IJARBSS/v9-i10/6458

Received: 25 September 2019, Revised: 1 October 2019, Accepted: 15 October 2019

Published Online: 29 Oct 2019

In-Text Citation: (Alonge Opeyemi Mojisola, 2019)

To Cite this Article: Alonge Opeyemi Mojisola. (2019). Herdsmen-Farmers Crisis and its Implication on Human Resource Management: The Nigeria Experience. International Journal of Academic Research in Business and Social Sciences, 9(10), 83-95.

Copyright: (C) 2019 The Author(s)

Published by Human Resource Management Academic Research Society (www.hrmars.com)

This article is published under the Creative Commons Attribution (CC BY 4.0) license. Anyone may reproduce, distribute, translate and create derivative works of this article (for both commercial and non-commercial purposes), subject to full attribution to the original publication and authors. The full terms of this license may be seen

at: http://creativecommons.org/licences/by/4.0/legalcode

Vol. 9, No. 10, 2019, Pg. 83 - 95

http://hrmars.com/index.php/pages/detail/IJARBSS

JOURNAL HOMEPAGE

Full Terms \& Conditions of access and use can be found at http://hrmars.com/index.php/pages/detail/publication-ethics 


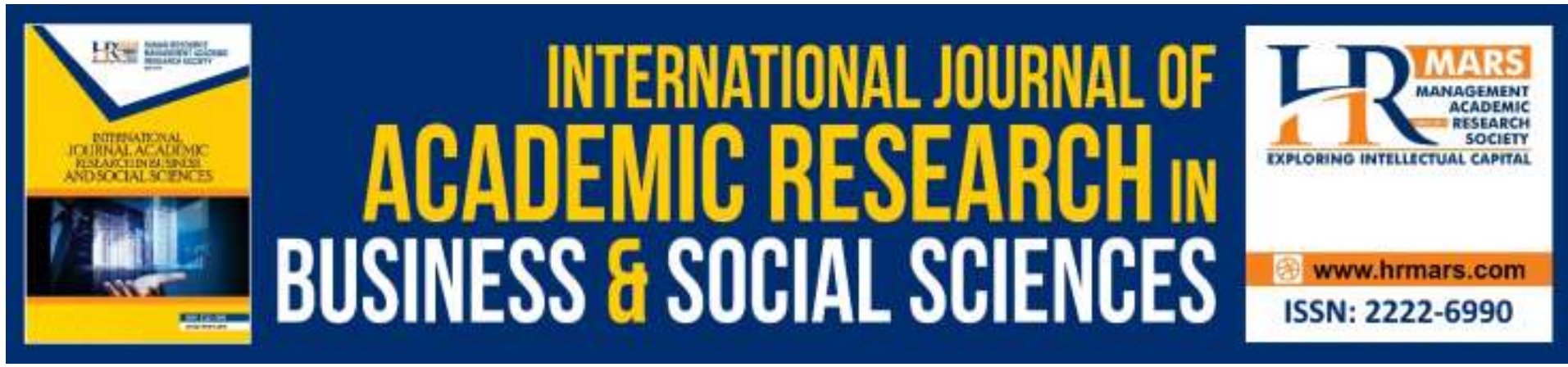

\title{
Herdsmen-Farmers Crisis and its Implication on Human Resource Management: The Nigeria Experience
}

\author{
Alonge Opeyemi Mojisola \\ Department of Public Administration, Rufus Giwa Polytechnic, Owo, \\ Ondo state, Nigeria. \\ Email: opeadewumi@yahoo.com
}

\begin{abstract}
The threat that herdsmen-farmers clash pose to human resource management is of numerous dimensions; ranging from displacement of workforce from kidnapping prone areas, threat to the firm's ability to attract diverse workforce in terms of gender and race, reduction in the pools from which prospective employees can be drawn, to disabilities of human resources arising from injuries sustained from clashes. Within literatures, few studies have been done to examine the implication of herdsmen-farmers crisis on human resource management. This paper examined the incessant killings and all sorts of violent attacks on lives and property by herdsmen in Nigeria and its implication on human resource management. Secondary source of data was used for this work. The findings from the study revealed that competition for land resources, climate change, among others are at the center of the crisis. This paper recommends improvement in the road infrastructure, so that attack scene can be easily reached for quick rescue of victims of attacks, collaborative efforts of government, traditional rulers and the local communities towards curbing the menace, unhealthy rivalry between security agencies should be curbed, so as to enhance collaboration and results, involvement of herdsmen and farmers representative in decision making towards curbing the menace, National Orientation Agency should aggressively campaign for peaceful coexistence, tolerance and accommodation among the citizens irrespective of diversity, and establishment of suitable cattle ranching reserves.
\end{abstract}

Keywords: Conflicts, Farmer, Herdsmen, Human Resource Management, Insecurity.

\section{Introduction}

In the earliest period in Nigeria, herders and farmers have co-existed peacefully without any fear or threat. Nzeh (2015) asserts that farmers-herdsmen have a cordial relationship in the time past before the relationship went bad. However, conflict between farmers and herdsmen resulted due to increased population of herdsmen and farmers thereby placing more demands on farmland (Aliyu, Ikedinma and Akinwande, 2018). Moritz (2003) found that conflict between farmers and herdsmen ensued from farmers' habit of extending the 
boundary of their farms to livestock routes and herdsmen habit of not resisting their herds from straying into farmer's farm to feed on their plants and litter the farm and pedestrian routes with dungs.

The primary concern of all human resource managers is to make the human resource available to the organization in the right quantity, right quality and at the right time. This has been very difficult to achieve in the recent time in Nigeria, as scores of human resources available to organizations are been displaced or maimed. The menace of herdsmen clashes is a major challenge, as most organizations are likely to contend with inadequate human resources to carry on the various activities that will lead to the achievement of the individual, organization and even the collective goal of economic development.

The farmers-herdsmen conflict in Nigeria is assuming a human resource management threatening dimension. The alarming dimension of the conflict has prompted many studies by different researchers. Most of the studies highlighted the causes to include the conflict caused by economic hardship, rapid increase in population, climate change, livestock invading farmers' farm, encroachment of livestock routes, rapping of female farmers, and pollution of water of communities by herds. The findings of these studies revealed loss of human lives and properties, displacement of people, reduction in farm produce among others are the consequences of the crisis in Nigeria (Abbass, 2012; Audu, 2013; Ofem \& Bassey, 2014; Nzeh, 2015; Doyin, 2017).

In the past researches little or nothing have been mentioned about human resource management implications of this menace. This calls for a research in this area.

The result of this study will be useful to government, policy makers and stakeholder by creating awareness about the detrimental consequence of the insecurity on human resource availability in Nigeria and also furnish them with information with which to formulate quality security-oriented policies and programmes that will make the state safe for human resources, thereby enhancing the productive capacity of organizations and the nation at large.

\section{Statement of the Problem}

Human resources have unique contribution to the organization and society at large because they are the ones that coordinate other organizational resources in an attempt to produce goods and services that is used by the members of the society thereby ensuring the achievement of organizational goals. Herdsmen-farmers clash have constituted serious threats to human resources management as the clashes did not only affect the herders and farmers alone but also those that live and have their workplace around the crisis prone areas. The crisis has affected human resources management in the area of availability of people to recruit from in the crisis areas as people are not willing to work in this crisis areas despite the high rate of unemployment prevalent in the country, even the human resources available to organizations are working with fear of attack, which has prevented them from contributing meaningfully in the workplace. The increasing number of reports of violence and manpower lost to those attacks are worrisome. Given the huge contribution of human resource to the achievement of organizational goals makes understanding and resolution of herder-farmer conflicts an urgent task.

\section{Objective of the Study}

This study intends to:

I. Determine the causes of herdsmen-farmers crisis in Nigeria. 
II. Ascertain the implication of herdsmen-farmers crisis on human resource management.

III. Recommend measures that can be used to resolve the crisis.

\section{Significance of the Study}

Many research studies have been conducted on herdsmen and farmers attack. Despite these studies, communities are still bedeviled with incessant attacks resulting in security threats to individuals, organisation and the nation at large. The need for further research work on herdsmen-farmers clash becomes necessary. It is on this basis that these studies assess the implication of herdsmen - farmers clash on human resource management. The information from this study will be of immense value to government, particularly, Federal Government of Nigeria, taking cognizance of the fact that the duty of government is to protect life and properties of all the citizens and foreigners living in a nation without which consistent production of goods and services will be hampered. Organisations will benefits from this study as adequate security provision for the human resource will mean more availability of pools of talent, from which organizations can recruit, retain and maintain for its productive activities. The Non-Governmental Organization (NGOs) would also benefit from the result of the study especially in their effort to coordinate their projects meant to ensure peaceful coexistence among all citizens irrespective of their differences thereby, improve the standard of people. The study will also be useful and beneficial to policy makers, researchers and planners, as it will serve as basis for further research and reform.

\section{Conceptual Framework}

\section{Human Resource Management}

Human resource management (HRM) can be defined as all management decisions and actions that affect the relationship between the organization and employees. It deals with the acquisition, utilization, maintenance and separation of people from the organization. Armstrong (2006) sees human resources management as a strategic and coherent approach to the management of an organization's most valued assets - the people working there who individually and collectively contribute to the achievement of its objectives. Human resource management is concerned with the human beings in an organization. Human resource management gives the organization an opportunity to utilize the manpower not only for the benefits of the organization but for the growth, development and self-satisfaction of the concerned people. Human resource management is a system that focuses on human resources development on one hand and effective management of people on the other hand so that people will enjoy human dignity in their employment (Ganesan, 2014).

In specific term, Human resource management is management function that involves recruitment, selection, training and development of organization members. This implies acquiring their services, developing their skills, motivating them to high levels of performance and ensuring that they continue to maintain their commitment to the organization are essential for achieving organizational objectives. This holds, irrespective of the type of organization; profit oriented or non-profit oriented.

HRM is a process of making efficient and effective use of human resources in an organization so that the set goals are achieved. Having regard for the well-being of the individuals and of working groups, will enable them to make their best contribution to the success of an organization. 


\section{Herdsmen- Farmers Crisis}

Human resource management in Nigeria has been threatened by incessant violence. The herdsmen are predominantly Fulani tribe. The Fulani's are majorly nomadic in nature, moving from one to the other with their animals in searcher of greener pastures for their herds. They are spread over many countries, particularly West Africa region. In Nigeria, the Fulani and the Hausa people dominate the northern states, and they are present in most state across the country (Adetula, 2016).

Conflict between herdsmen and farmers have been in existence since the beginning of agriculture and increased or decreased in intensity and frequency due to factors such as increase in the herd sizes, due to improved conditions of the cattle, making pastoralists to seek for more pastures beyond the ones freely available to them, thereby putting more pressures on the land resources (Bello, 2013).

The herdsmen have been known for violence and attack of certain communities in the country, but the rate of attack has been on the increase in the recent time. Record provided by the Institute for Economics and Peace estimated 1,229 and 63 people to have been killed through Herders - Farmers violence in 2014 and 2013 respectively. In May 2015, over 100 farmers and their family were killed in villages and refugee camps located in the Ukuraper, Gafa and Tse - Gusa local government areas of Benue State (Adetula, 2016). This crisis between herdsmen and farmers has become worrisome as there have been several clashes resulting to loss of lives and properties, displacement and joblessness (Lawal, Adelakun, \& Akindiyo (2018).

\section{Empirical Framework}

Ajibefun (2018) conducted a study on the Social and Economic Effects of the Menace of Fulani Herdsmen Crises in Nigeria. The study specifically examined the causes of the menace of Fulani and farmers clashes in Nigeria. Questionnaire was used for data collection using purposive sampling technique. Descriptive statistics and inferential statistics of $t-$ test was used for data analysis. The findings revealed that the destruction of crops was the major cause of the clashes.

Aliyu \& Akinwande (2018) in their study on the Assessment of the Effect of Farmers-Herdsmen Conflicts on National Integration in Nigeria, examined incidents of farmers herdsmen conflicts, its causes and effects on national integration in Nigeria. The study employed case study research design, used secondary data and was content analyzed. The study found that farmers-herdsmen conflicts are caused by many factors such as limited resources in the face of unlimited need, reprisal attack, shortages of land and climate change.

\section{Theoretical Framework}

Frustration-Aggression Theory

Frustration aggression theory has been written a long time before the wave of insurgencies, but it has relevance in the explanation of modern-day violence. Ted Gurr (1970) in his book "Why Men Rebel" explores why people take to violence. In Gurr's opinion, frustration is the major source of aggression. When frustration is sufficiently prolonged and sharply felt, anger and violence is inevitable. Gurr explained this hypothesis with his term "relative deprivation", which is the difference between what people think they deserve, and what they actually think they can get. The major assumption in Gurr's book is that "the potential for collective violence varies strongly with the intensity and scope of relative deprivation among members of a 
collectivity". In his opinion, the way frustration produces aggressive behaviour on the part of an individual, so does relative deprivation of social group lead to collective violence.

Major point in Gurr's work is that men are quick to aspire beyond the resources available to them and quick to anger when those resources prove inadequate, but slow to accept their limitations. Relative deprivation is the tension between your actual state, and what you feel you should be able to achieve. Although aggression is neither necessary nor sufficient but the more prolonged a feeling of frustration, the greater the probability of aggression.

Deprivation occurs when your value expectations exceeds your value capabilities. After writing volumes about the non-rational causes of violence. He added a passage on the rational utilities of violence; people act out their frustration if they believe that they can be relieved from their discontent by going violent and if previous success of collective violence helps determine perceived utility of violence (Gurr, 1970). In the context of this discussion frustration results from the competition from limited land resources, insatiable quest for power, religious extremism, unemployment and corruption among others.

\subsection{CONFLICT THEORY}

Conflict theory is relevant in proving the fact that competition for access to natural resources between farmers and herders gives rise to conflict. It sets the background for the origin of the conflict in terms of access to the means of production. Conflict is inevitability when competing for scarce resource. Land which is a valuable resource is the bone of contention in present day tension and conflicts between Fulani herdsmen and host communities. Conflict usually occurs when the herdsmen intrude and feeds upon the crops of the farmers or agricultural products and other essential facilities in the regions. Rational farmer will not be calm and watch their means of livelihood being destroyed by herdsmen cattle. As a result of this clash is bound to ensue. The main thrust of the conflict is the loss of the means of livelihood. Ekong (2003), sees conflict as that form of social interaction in which the participants seek to obtain scarce resources by eliminating or weakening their contenders. Conflict is a fight for control of one or group of persons by the other in so as to subject or even eliminate the opponent. Some selected cases of herdsmen attack from January to April, 2018, as compiled by Tolu, Adelakun, \& Akindiyo, (2018).

\section{Incidences of Herdsmen Attack in Nigeria}

The high incidence of clashes and lots of attacks of farmers by herdsmen has become issue of concern to well-meaning Nigerian and the international communities. The attacks are unprecedented when assessed on the basis of the frequency, the casualty, and sheer brutality. This dastardly act has questioned peaceful co-existence of different ethnic groups in Nigeria, and has also forced various states to respond swiftly to security alerts. 
Table 1: Selected Cases of Attack by Herdsmen, January - April, 2018

\begin{tabular}{|c|c|c|c|}
\hline $\mathrm{S} / \mathrm{N}$ & Nature of Attack & Date of Attack & Source of Information \\
\hline 1. & $\begin{array}{l}50 \text { Benue indigenes killed } \\
30 \text { injured in logo Benue }\end{array}$ & January 1, 2018 & $\begin{array}{l}\text { http://punchng.com/herdsmen-killed- } \\
\text { 50-injured-30-inBenue.htm }\end{array}$ \\
\hline 2. & $\begin{array}{l}2 \text { Nasarawa farmers killed in } \\
\text { Awe, Nasarawa }\end{array}$ & January 1, 2018 & $\begin{array}{l}\text { http://punchng.com/flrring-herdsmen- } \\
\text { allegedly-kill-Nasarawafarmer }\end{array}$ \\
\hline 3. & $\begin{array}{l}25 \text { Nasarawa farmers killed in } \\
\text { Keana, Nasarawa }\end{array}$ & January 1, 2018 & $\begin{array}{l}\text { http://punchng.com/death-tollhits-25- } \\
\text { in-Nasarawa-herdsmen-farmers-crisis }\end{array}$ \\
\hline 4. & $\begin{array}{l}\text { Village head and } 15 \text { others } \\
\text { attacked and killed in Logo, } \\
\text { Benue }\end{array}$ & January 6, 2018 & $\begin{array}{l}\text { http://www.vanguardng.com/2018/01/ } \\
\text { village-head-15-others-killed-fresh- } \\
\text { herdsmen-attack }\end{array}$ \\
\hline 5. & $\begin{array}{l}60 \text { indigenes attacked and killed } \\
\text { in Lau, Taraba }\end{array}$ & January 5, 2018 & $\begin{array}{l}\text { www.premiumtimesng.com/news/headl } \\
\text { ine/254650- tarabacommunities- } \\
\text { attacked-fulani-bachama-groups- } \\
\text { accused.html }\end{array}$ \\
\hline 6. & $\begin{array}{l}\text { Herdsmen attacked and killed } 1 \\
\text { in Ibi, Taraba }\end{array}$ & January 14, 2018 & $\begin{array}{l}\text { File://localhost/tp/:http//punchng.com: } \\
\text { armed-fulanimen-attack-taraba- } \\
\text { community-kill-traditional-ruler. }\end{array}$ \\
\hline 7. & $\begin{array}{l}\text { Hunter killed in Barkin ladi, } \\
\text { Plateau }\end{array}$ & January 20, 2018 & $\begin{array}{l}\text { http://punchng.com/suspected- } \\
\text { herdsmen-kill-hunter-in-plateau/ }\end{array}$ \\
\hline 8. & $\begin{array}{l}\text { Reprisal attack leaves } 6 \text { dead in } \\
\text { Juman, Adamawa }\end{array}$ & January 21, 2018 & $\begin{array}{l}\text { http://saharareporters.com/2018/01/23 } \\
\text { /herdsmen-attack-reprisal-claims-six- } \\
\text { lives-adamawa }\end{array}$ \\
\hline 9. & $\begin{array}{l}\text { Herdsmen kill } 7 \text { in bokkos } \\
\text { Plateau state, }\end{array}$ & January 24, 2018 & $\begin{array}{l}\text { http://sunnewsonline.com/suspected- } \\
\text { herdsmen-kill-7-injure-manyinplateau/ }\end{array}$ \\
\hline 10. & $\begin{array}{l}\text { Attack in Bassa, Plateau state. } 8 \\
\text { locals killed }\end{array}$ & January 25, 2018 & $\begin{array}{l}\text { http://Sunnewsonline.com/suspected- } \\
\text { herdsmen-kill-8-injure- } \\
\text { personsinplateau/ }\end{array}$ \\
\hline 11. & 2 killed in Bassa, Plateau state. & January 28, 2018 & $\begin{array}{l}\text { http://sunnewsonline.com/2- } \\
\text { killedinplateau-as- } \\
\text { herdsmenambushresdents/ }\end{array}$ \\
\hline 12. & $\begin{array}{l}\text { NNPC workers attacked and } 1 \\
\text { killed in Guma, Benue }\end{array}$ & January 29, 2018 & $\begin{array}{l}\text { http://www.vanguardngr.com/2018/01/ } \\
\text { breaking-herdsmen-attacknnpcofficials- } \\
\text { workin-petroleum-benuestate/ }\end{array}$ \\
\hline 13. & $\begin{array}{l}\text { Herdsmen killed } 9 \text { in Birnm } \\
\text { Gwari, Kaduna }\end{array}$ & January 31, 2018 & $\begin{array}{l}\text { http://saharareporters.com/2018/02/01 } \\
\text { /suspected-fulani-herdsmen-kill-9- } \\
\text { kaduna/ }\end{array}$ \\
\hline
\end{tabular}


INTERNATIONAL JOURNAL OF ACADEMIC RESEARCH IN BUSINESS AND SOCIAL SCIENCES

Vol. 9, No. 10, October, 2019, E-ISSN: 2222-6990 @ 2019 HRMARS

\begin{tabular}{|c|c|c|c|}
\hline 14. & 2 killed in Song, Adamawa & February 2, 2018 & $\begin{array}{l}\text { http://sunnewsonline.com/2-killed- } \\
\text { village-razed-in-herdsmen-farmers- } \\
\text { clash-in-adamawa/ }\end{array}$ \\
\hline 15. & $\begin{array}{l}\text { Herdsmen attack Gov. Ortorm } \\
\text { farm house and kill } 2\end{array}$ & February 5, 2018 & $\begin{array}{l}\text { www.vanguardngr.com/2018/02/herds } \\
\text { men-attack-sack-gov-ortoms-farmhouse }\end{array}$ \\
\hline 16. & $\begin{array}{l}\text { Herdsmen ambush and kill } 2 \\
\text { police officers }\end{array}$ & $\begin{array}{l}\text { February 10, } \\
2018\end{array}$ & $\begin{array}{l}\text { http://saharareporters.com/2018/02/11 } \\
\text { /four-officers-missing- } \\
\text { herdsmenambush-police-team-benue }\end{array}$ \\
\hline 17. & 4 killed in Jema'a, Kaduna & $\begin{array}{l}\text { February 11, } \\
2018\end{array}$ & $\begin{array}{l}\text { http://punching.com/suspected-fulani- } \\
\text { herdsmen-kill-four-in-kaduna-village }\end{array}$ \\
\hline 18. & $\begin{array}{l}2 \text { civil defence officers killed in } \\
\text { Guma, Benue }\end{array}$ & $\begin{array}{l}\text { February 12, } \\
2018\end{array}$ & $\begin{array}{l}\text { http://saharareporters.com/2018/02/12 } \\
\text { /suspected-fulani-herdsmen-kill-two- } \\
\text { nscdc-officers-benue }\end{array}$ \\
\hline 19. & 20 killed in Demsa, Adamawa & $\begin{array}{l}\text { February 27, } \\
2018\end{array}$ & $\begin{array}{l}\text { http://sunnewsonline.com/herdsmen- } \\
\text { 20-killed-23injured-inadamawa }\end{array}$ \\
\hline 20. & 24 killed in Okpokwu Benue & March 5, 2018 & $\begin{array}{l}\text { http://punching.com/updated-benue- } \\
\text { herdsmen-attack-death-toll-now-24 }\end{array}$ \\
\hline 21. & 11 killed in Bassa, Plateau & March 8, 2018 & $\begin{array}{l}\text { http://punching.com/herdsmen-kill-11- } \\
\text { torch-50- housesinplateau }\end{array}$ \\
\hline 22. & 2 brothers killed in Guma Benue & March 13, 2018 & $\begin{array}{l}\text { Saharareporters.com/2018/03/14/herds } \\
\text { men-kills-two-brothers-Benue }\end{array}$ \\
\hline 23. & 32 killed in Daima/ Omala, kogi & March 14, 2018 & $\begin{array}{l}\text { http://www.premiumtimesng.com/regi } \\
\text { onal/north-central/261907-32-killed-in- } \\
\text { kogi-by-suspected-herdsmen- } \\
\text { senator.htm/ }\end{array}$ \\
\hline 24. & $\begin{array}{l}\text { Herdsmen kill } 2 \text { soldiers in Rafiki, } \\
\text { Bassa, Plateau }\end{array}$ & March 14, 2018 & $\begin{array}{l}\text { http://www.vanguardngr.com/2018/03/ } \\
\text { herdsmen-youths-clash-plateau- } \\
\text { 2operation-safe-haven-personnel-killed- } \\
\text { 2-othersinjured }\end{array}$ \\
\hline 25. & $\begin{array}{l}\text { Herdsmen kill } 4 \text { soldiers in } \\
\text { Miango, Bassa, Plateau }\end{array}$ & March 14, 2018 & $\begin{array}{l}\text { http://saharareporters.com/2018/03/17 } \\
\text { /fulani-herdsmen-kill-4-soldiers- } \\
\text { garrison-commanders-convoy-injure- } \\
\text { scores-plateau }\end{array}$ \\
\hline 26. & $\begin{array}{l}\text { Attack on Takum, Taraba leaves } \\
5 \text { dead }\end{array}$ & March 15, 2018 & $\begin{array}{l}\text { http://www.vanguardngr.com/2018/03/ } \\
\text { five-people-killed-houses-razed- } \\
\text { herdsmen-attack-Taraba-community }\end{array}$ \\
\hline 27. & 5 killed in Makudi, Benue & March 24, 2018 & $\begin{array}{l}\text { http://punchng.com/5-die-infresh- } \\
\text { fulani-crisis-in-benue }\end{array}$ \\
\hline
\end{tabular}


INTERNATIONAL JOURNAL OF ACADEMIC RESEARCH IN BUSINESS AND SOCIAL SCIENCES Vol. 9, No. 10, October, 2019, E-ISSN: 2222-6990 @ 2019 HRMARS

\begin{tabular}{|c|c|c|c|}
\hline 28. & $\begin{array}{l}\text { Herdsmen kill } 10 \text { in Gwer west, } \\
\text { Benue }\end{array}$ & April 4, 2018 & $\begin{array}{l}\text { http://sunnewsonline.com/10-killed- } \\
\text { injured-fulani-herdsmenbenue }\end{array}$ \\
\hline 29. & 5 kill in Dobga, Taraba & April 5, 2018 & $\begin{array}{l}\text { http://sunnewsonline.com/herdsmen- } \\
\text { killed-5-thurday-attack-tarabavillage }\end{array}$ \\
\hline 30. & $\begin{array}{l}\text { Father and son killed in Agatu, } \\
\text { Benue }\end{array}$ & April 7, 2018 & $\begin{array}{l}\text { http://punchng.com/herdsmen-attack- } \\
\text { benue-community-kill-father-son/ }\end{array}$ \\
\hline 31. & 4 killed in Keana, Nasarawa & April 8, 2018 & $\begin{array}{l}\text { http://sunnewsonline.com/herdsmen- } \\
\text { farmers-crisis-gunmen-kill-4-persons-in- } \\
\text { reprisal-attack-in-Nasarawa }\end{array}$ \\
\hline 32. & Soldier kill in Guma, Benue & April 9, 2018 & $\begin{array}{l}\text { https://www.vanguardngr.com/2018/04 } \\
\text { /soldier-kill-herdsmen-invade-another- } \\
\text { benue-community }\end{array}$ \\
\hline 33. & Herdsmen kill 31 in Guma, Benue & April 20, 2018 & $\begin{array}{l}\text { http://www.vanguardngr.com/2018/04/ } \\
\text { another-31-kill-benue/ }\end{array}$ \\
\hline 34. & $\begin{array}{l}\text { Herdsmen raid and kill } 2 \text { priest } \\
\text { and } 17 \text { others, Gwer East, Benue }\end{array}$ & April 25, 2018 & $\begin{array}{l}\text { http://www.vanguardngr.com/2018/04/ } \\
\text { fresh-bloodbath-benue-2-catholic- } \\
\text { priest-17-others-killed-herdsmen }\end{array}$ \\
\hline 35. & $\begin{array}{l}\text { Herdsmen attack and kill } 7 \text { in } \\
\text { Awe, Nasarawa }\end{array}$ & April 25, 2018 & $\begin{array}{l}\text { http://www.punchng.com/suspected- } \\
\text { herdsmen-kill-7-in-Nasarawa- } \\
\text { communal-clash-death }\end{array}$ \\
\hline
\end{tabular}

Compiled by Tolu, \& Adelakun, \& Akindiyo, (2018).

The cases above, showed the consistency of the attack and the number of manpower lost to it. Clashes between herdsmen and crop farmers are a major cause of consistent crisis and general insecurity in Nigeria. These attacks leave many human resources displaced, wounded, disabled and killed. The frequency and scale of these conflicts is a threat to effective management of human resources.

This was further corroborated by the acting Inspector-General of Police, Mohammed Adamu, who revealed that a total of 1,071 people was killed in crime-related cases across the country in the first quarter of 2019. The Police chief disclosed this in Kaduna State at the quarterly Northern Traditional Rulers' Council meeting which took place on Tuesday, April 30, 2019. (https://www.pulse.ng/news/local/igp-says-1071-people-killed-685-kidnapped-innigeria-in-2019/681pntp)retrieved Retrieved on July 18, 2019).

\section{Government Efforts so Far}

Oyo state government in May 2016, established grazing lands, feedlots and ranches for herdsmen and their cattle in the state and concurrently outlawed night grazing and straying of cows outside the proposed enclosed designated grazing areas, Ekiti state government also banned cattle rearing and grazing in the state in the same year and in year 2017 Benue state government enacted law against open grazing in the state. (Toromade, 2018). 
Open Grazing Prohibition and Ranches Establishment Bill (2017).

Objectives of Open Grazing Prohibition law by Benue state government include;

Preventing destruction of crop farms, ponds, settlements and property by open rearing and grazing of livestock as well as cattle rustling, thereby curbing incessant conflicts between nomadic livestock herders and farmers.

The law protects both herders and farmers. Section 20 of the law provides

i. Any person(s) who rustles cattle, or other animals from any ranch commits an offence and shall be liable on conviction for imprisonment for a term of not less than three (3) years or One Hundred Thousand Naira $(N 100,000.00)$ per animal or both.

ii. Where a rustler: injures, or maims any person while carrying out his activities he shall on conviction be reliable to five (5) years imprisonment or a fine of Five Hundred Thousand Naira only $(\mathrm{N} 500,000.00)$ only or both; cause death, he shall be guilty of an offence of culpable homicide punishable under the provision of the penal code;

iii. A person convicted of cattle rustling may, in addition pay compensation to the victim or owner as the court may direct.

\section{Methodology}

The study basically relied on secondary data collected through different publications and archives such as the international agencies reports, news item, texts, journals, magazines, Newspapers, Bulletin and the internet.

\section{Herdsmen-Farmers Crisis and Its Implication on Human Resource Management}

A threat to the life of people is a threat to the human resource management.). This crisis between herdsmen and farmers has become worrisome as there have been several clashes resulting to loss of lives and properties, displacement and joblessness Lawal, et al, (2018). The underlisted are some of the implications.

i. Manpower planning - The availability of human resource in the right quantity, quality, at the right time is what makes for effective human resource management. This implies availability of the human resource in the required number, qualification, skills and competence as at when needed with the right placement. Anything short of this will affect the smooth running of the organization. People killed during violent clashes will affect manpower planning of organizations.

ii. Reduction in the output of human resource - Productivity is the ratio of the quantity and quality of units produced to the labor per unit of time. Meeting the increasing demand to provide improved goods and services to an increasingly diverse customer base is hampered when employees live with perpetual fear of violent attack on them and their properties. Deformity and body harm to employees' due violent clashes will affect their attitude and contribution to organization goals and objectives.

iii. Talented employees who are highly sought after, are easily attracted by organizations in a peaceful and conducive environment. Inability to retain talented and valuable employees due to fear of attack, result in lost investments in recruitment and training for organizations in crisis prone areas.

iv. Diversity: Diversity management implies recognizing, understanding and accepting individual differences irrespective of their race, gender, age, class, ethnicity, physical 
ability, race, sexual orientation, spiritual practice and so on. Diversity encompasses a wide range of differences, including gender, cultural background, work experience, educational background, geographic location, and much more. Heterogeneity promotes creativity, produce better solutions to problems and a higher level of critical analysis. This can be a vital asset at a time when the organization is undergoing tremendous change in order to find new and more effective ways to operate. With effective management of diversity, the organization develops a reputation as an employer of choice. Not only will the organization have the ability to attract the best talent from a shrinking labor pool, it can also save time and money in recruitment and turnover costs when the environment in which the business operates is safe. Organizations ability to diversify its human resource in terms of gender, tribe and religion, is been threatened in the face of herdsmen-farmers crisis.

\section{Conclusion}

This paper has critically examined herdsmen - farmers' conflict in Nigeria. In it, various factors responsible for the conflict were thoroughly investigated and the effects of such conflicts on human resource management were adequately captured and analyzed. It was observed that the conflict between herders and farmers is not a phenomenon of recency in Nigeria, as it has always been cases of encroachment into farmlands and cattle rustling.

In every productive endeavor, human resources are the ones that coordinate all other organizational resource so as to ensure the actualization of the goals and objectives of the organization. Nigeria's security problem is draining her of human resource; the most valuable resource available to her. The rate at which human lives are lost to the violent herdsmenfarmers attack, has assumed an alarming dimension. Many of the victims have been maimed or injured making them incapacitated. The herders and farmers must embrace tolerance and peace in order to provide conducive environment where organization can get required human resources in the right quantity, quality and at the right time. This study is limited to the herders-farmers crisis as a form of security threat to organization and nation at large. This study can be extended by other researchers to other forms of security threats like kidnapping, armed banditry to mention a few. The recommendation of this paper will help policy makers on proffering solution to the herders-farmers crisis.

\section{Recommendations}

The consequences of herdsmen-farmers crisis are enormous to victims, organization and the society at large but the following recommendations can be adopted to reduce or put a stop to the crisis.

I. Improvement in the road infrastructure, so that attack scene can be easily reached for quick rescue of victims of attacks.

II. Collaborative efforts of government, traditional rulers and the local communities should be adopted towards curbing the menace.

III. Unhealthy rivalry between security agencies should be curbed, so as to enhance collaboration and results.

IV. Involvement of Fulani herdsmen and farmers representative in decision making towards curbing the menace. 
V. National Orientation Agency should aggressively campaign for peaceful coexistence, tolerance and accommodation among the citizens irrespective of diversity.

VI. Establishment of suitable cattle ranching reserves for herdsmen in any community that welcome the idea.

\section{References}

Abbass, I. M. (2012). No Retreat No Surrender: Conflict for Survival Between Fulani Pastoralists and Farmers in Northern Nigeria. European

Science Journal, (1), 331 -346.

Adetula, D. (2018). Understanding the Fulani Herdsmen Crisis in Nigeria: Here is Everything you Need to know, 2016, Retrieved from

https//www.ventures Africa.com/ weekly - economic- index- foreign- reservescontinue- to rise- oil- price. Retrieved on April 25th, 2018.

Ajibefun, M. B. (2018). Social and Economic Effects of The Menace of Fulani Herdsmen Crises in Nigeria. Journal of Educational and Social

Research, 8(2), $133-139$.

Aliyu, M. K., Ikedinma, H. A, \& Akinwande, A. E. (2018). Assessment of the Effect of FarmersHerdsmen Conflicts on National Integration

in Nigeria. International Journal of Humanities and Social Sciences, 8 (10), 118 - 128.

Armstrong, M. (2006). A Handbook of Human Resource Management Practice. Kogan Page Limited. UK, $10^{\text {th }} \mathrm{Ed}$.

Audu, S. D. (2013). Conflicts Among Farmers and Pastoralists in Northern Nigeria Induced by Freshwater Scarcity. International Institute of Science, Technology and Education Journal. 3(12), 2013, 25 -32

Bello, A. U. (2013). Herdsmen and Farmers conflicts in North - Eastern Nigeria: Causes, Repercussions and Resolutions. Academic Journal

of Interdisciplinary studies, 2 (5)

Doyin, T. (2017). An Empirical Investigation to Incessant Killings in Nigeria. Journal of Philosophy, 5, 2017, $67-82$.

Ganesan, S. (2014). Introduction of Human Resource Management, International Journal of Business and Administration Research Review,

I (6), 147.

Ekong, E. E. (2003). An Introduction to Rural Sociology $\left(2^{\text {nd }}\right.$ ed.). Uyo, Nigeria: Dove Educational Publishers.

Gurr, T. (1970). Why Men Rebel. Princeton, NJ: Princeton University Press.

Moritz, M. (2003). The Demise of the Nomadic Contract: Arrangements and Rangelands under Pressure in the Far North of Cameroon. Normadic People, 6(1), 127 -146.

Nzeh, E. (2015). The Effects of Migration by Nomadic Farmer in the Livelihoods of Rural Crop Farmers in Enugu State, Nigeria. Global Journal of Science Frontier Research, 15(3), 45-56.

Ofem, O. O., and Bassey, I. (2014). Livelihood and Conflict Dimension Among Crop Farmers and Fulani Herdsmen in Yakurr Region of Cross River State., Mediterranean Journal of Social Sciences. 5(8), $512-519$.

Tolu, L. \& Adelakun, O. \& Akindiyo, O. (2018). Herdsmen Debacle in Nigeria: The Implication on Stability and Food Security, SocialSci 
INTERNATIONAL JOURNAL OF ACADEMIC RESEARCH IN BUSINESS AND SOCIAL SCIENCES

Vol. 9, No. 10, October, 2019, E-ISSN: 2222-6990 @ 2019 HRMARS

Journal, 2, $203-210$

Toromade, S. (2018). Benue Crisis. What you need to know about Fulani Herdsmen, Anti Open Grazing Law, Miyetti Allah. Freedom 